\title{
Instructional Learning Teams: A Case Study
}

\author{
Jonathan L. Brendefur ${ }^{1, *}$, Brian Whitney ${ }^{1}$, Roger A. Stewart ${ }^{1}$, Joshua Pfiester ${ }^{1} \&$ Julia Zarbinisky $^{1}$ \\ ${ }^{1}$ Curriculum, Instruction and Foundational Studies, Boise State University, Boise, USA \\ *Corresponding author: Boise State University, 1910 University Drive, Boise, ID 83725, USA. Tel: 1-208-426-2468. \\ E-mail: jbrendef@boisestate.edu
}

Received: December 1, 2013

Accepted: January 6, $2014 \quad$ Online Published: January 13, 2014

doi:10.5430/jct.v3n1p36

URL: http://dx.doi.org/10.5430/jct.v3n1p36

\begin{abstract}
Changing teacher practices to improve student learning is a challenge. For teachers' practices to change, faculties within schools must build communities of practice. However, supporting teachers' collaborative learning within a Professional Learning Team can be an elusive challenge. We found through the Instructional Learning Team (ILT) model of professional development that teachers have a focused model to make effective changes to their practice. ILTs promote school improvement by providing a process through which teachers collaboratively focus on sustained reflection about student learning tasks, instruction, and student work using the Japanese Lesson Study and critiquing their work using Newmann's (1996) Intellectual Quality framework. We followed two teams of teachers over a semester and qualitatively examined changes in four elements of professional learning: shared ideas and values, focus on student learning, reflective dialogue, and deprivatization of practice. Through the ILT process all four elements of professional learning communities increased. This process of changing practice through examining instructional tasks, practices and student work has a direct impact on helping teachers move toward implementing the Common Core State Standards (CCSS).
\end{abstract}

Keywords: teacher education; teacher practice; professional development

\section{Literature Review}

Changing teacher practices to improve student learning is a challenge in United States public schooling. According to DuFour and Eaker (1998) and Smith (2003), for teachers' practices as a whole to change, faculties within schools must build communities of practice (Wenger, 1998). Improved practices can be achieved through a collaborative environment focusing on the instruction, curricular materials and student work (Newmann \& Associates, 1996). A professional development model: Instructional Learning Teams (ILTs) promote school improvement by providing a process through which teachers collaborate with other professionals using rubrics to guide reflective discourse regarding tasks, instruction, and student work while engaging in short cycles of informal action research (Newmann, Secada, \& Wehlage, 1995; Stewart \& Brendefur, 2005b). For over a century, U.S. teachers have been disenfranchised as passive receivers of university-based research. We aim to contribute to Stenhouse's argument that teacher "research [is] the route to teacher emancipation" (cited in Cochran-Smith \& Lytle, 1993, p. 8). In order for teachers to examine their work in ways to increase student understanding, we combined the Japanese Lesson Study, intellectual quality and professional learning communities. The purpose of this paper is to describe how these elements of research are put together to form Instructional Learning Teams (ILTs) and to describe the results of two case studies implementing ILTs.

The ILT model allows teachers a meaningful way to examine their practices. It provides them with a framework for new discourse, acculturating them into a learning community committed to working on improved practice and improved student learning and performance. This type of team and individual study is a "rigorous examination of one's own practice as a basis for professional development, the idea is that each school, and indeed each classroom, is a laboratory in which the curriculum and problems experienced as problems by teachers are subjected to empirical examination by practitioners" (Henson, 1996, p. 53).

Learning to teach well, even for veteran teachers, is a complex, uncertain, and difficult task. However, quality teaching is an essential ingredient to increasing student achievement and promoting student understanding (Haycock, 
2001; Newmann \& Associates, 1996; Nye, Kostantopoulos, \& Hedges, 2004). This argument rests on the premise that if schools want students to read well, do mathematics and science, understand history, solve problems, communicate ideas, and reason, then we have to provide teachers with different professional development opportunities than they have had in the past (Darling-Hammond, Wei, Andree, Richardson, \& Orphanos, 2009; Stigler \& Hiebert, 1999).

One key to promoting and increasing student achievement lies in improving instructional practices. The literature is ripe with examples and evidence that changing teachers' instructional practices is difficult because of the cultural nature of living within a specific and constrained community of teaching practice (Frykholm, 2004; Hiebert \& Stigler, 2000; Zeichner \& Gore, 1990). There are also a handful of examples that clearly demonstrate teachers can change their practices to be more consistent with what the reform documents suggest (see MSEB, 1990; NCTM, 2000) and increase student achievement on standardized measures and promote deeper understanding of ideas.

\subsection{Japanese Lesson Study}

The Japanese Lesson Study process, which gained international prominence during the Third International Mathematics and Science Study (TIMSS) (Hiebert \& Stigler, 2000; Lewis, 2002; Stigler \& Hiebert, 1999), is similar to action research - cycles of informal research or reflective problem solving initiated by practitioners - in that it is a systematic inquiry about an instructional problem. While lesson study forms the core of Japanese professional development, it is still a novelty for U.S. teachers. This is not surprising to most teacher educators because it is not routine for U.S. universities to prepare preservice or inservice teachers to conduct classroom research or study their practice (Darling-Hammond et al., 2009; Lampert \& Ball, 1999). In fact, "the low involvement [in research] is attributable, at least in part, to the failure of preservice programs to prepare and require students to conduct research" (Henson, 1996, p. 55). Also, once actively practicing, "U.S. teachers participate in workshops and short-term professional development events at similar levels as teachers in other nations. But the United States is far behind in providing public school teachers with opportunities to participate in extended learning opportunities and productive collaborative communities" (Darling-Hammond et al., 2009, p. 6).

Teachers should not only engage with theory and practice in concert, but also become involved in lesson studies. This provides a format for all teachers to facilitate their development as professionals where they learn about their practice and increase student performance. As Japan is significantly different in social and educational characteristics, lesson study must be adapted to the U.S. context.

The lesson study process incorporates many elements of effective professional development experiences (Borko, Jacobs, Eiteljorg, \& Pittman, 2008; Desimone, 2009; Heck, Banilower, Weiss, \& Rosenberg, 2008; Hord, 1997; Lewis, 2002). The steps include:

1) Collaboratively identify a question or difficulty the team would like to explore.

2) The team investigates current research on the identified issue that enables them to become knowledgeable about best teaching practices and to learn how students' think about that topic.

3) The team creates a lesson or series of lessons addressing the identified issue.

4) One team member teaches the lesson, while others actively observe, take notes, and, if possible, videotapes the lesson. This documentation of teaching and learning provides an avenue for the next step.

5) The team engages in processing reactions, reflections, and modifications of the lesson. During this process, teachers investigate the instructional strategies chosen and the student responses using these data to generate alternate possibilities, leading to a modification of the lesson(s).

6) A different team member teaches the modified lesson. Steps 4 through 6 repeat until the team is comfortable with the results. Following this, the lesson is analyzed as a whole in which student understandings and performances are acknowledged and attributions to success or failure are delineated.

7) Every lesson study concludes with a detailed written report that can be employed by other teachers in their classrooms (Henson, 1996; Lewis, 2002).

\subsection{Intellectual Quality}

Because professional development experiences similar to lesson study or action research are not common place in the U.S. and because educators are not used to critiquing their own and peer's practice, we use the lens of intellectual quality to frame teachers' discourse within an ILT. Newmann and Associates (1996) proposed the use of rubrics for identifying what they called intellectual quality. In the ILT process, these rubrics (adapted from Newmann et al., 
1995; see Stewart \& Brendefur, 2005b) focused the discussion of team members around specific elements of the tasks given to students, the type of instructional practices performed, and work created by students as they engaged with the tasks and instruction. Three crucial components of the intellectual quality model reflected within the task, instruction, and student work rubrics include construction of knowledge, disciplined inquiry, and value beyond school (Newmann et al., 1995). The intellectual quality model has demonstrated that teachers whose pedagogy rates higher on the rubrics have students who perform higher on standardized achievement tests (ITBS, NAEP) than teachers who rate lower on the scales (Newmann \& Associates, 1996).

As educators, one of our charges is to foster ways of knowing which prepare students to make connections, to communicate about ideas, to reason, and to solve traditional and novel problems. $21^{\text {st }}$ century learning (Bellanca \& Brandt, 2010) and Common Core State Standards (NGA, 2010) both charge public schools with higher expectations of student engagement in authentic tasks, inquiry and problem solving. Newmann et al (1995) state that "judgments of intellectual quality applied to a lesson, assessment activity, or sample of student performance usually imply one or both of the following criteria: the legitimacy of the content . . . accuracy . . . [and] a third must be added . . . .authenticity" (p. 3). Newmann (1996) demonstrated that when teachers focused on construction of knowledge, disciplined inquiry, and value beyond instruction, students at differing cognitive abilities and backgrounds increased their scores on traditional achievement tests. With two new assessments (PARCC, 2013; SBAC, 2013) on the horizon, both will assess more elements than traditional tests: deeper conceptual understanding, problem solving, and reasoning (which includes the ability to critique others' reasoning). Newmann's criteria theoretically fit these new components, which may lead to an even stronger relationship between teachers' practices and student achievement. Intellectual quality is defined by these three constructs, which help organize content within the rubrics and are used during ILT collaborations.

\subsubsection{Construction of Knowledge}

Constructing or producing knowledge means that students engage with tasks that require making sense of a situation or phenomenon through discussions and exploration that rely on their prior knowledge and available resources (Newmann et al., 1995). This differs from asking students to reproduce or copy knowledge that has been given to them. When constructing knowledge authentically rarely is there merely one way to derive a solution and at times there is the opportunity for more than one correct solution to be found.

\subsubsection{Disciplined Inquiry}

Disciplined inquiry relates to the intellectual processes students go through while solving problems (Newmann et al., 1995). These processes include three components: use of prior knowledge, development of in-depth understanding, and elaborated communication. Prior knowledge consists of each student's existing knowledge of facts, rules, algorithms (whether informal or formal), and general knowledge relevant to the problem at hand. In most conventional classrooms, which include k-12 and university courses, teachers remind students of applicable prior knowledge they should have learned and then present problems for students to practice reproducing this knowledge (Frykholm, 2004). This type of rote practice does not afford students with opportunities to build relational knowledge, where existing understandings are used to make sense of new information. Development of in-depth understanding requires students sustain a focus on a significant topic, demonstrate complex understandings by arriving at conclusions, or explain how complex problems may be solved. Elaborated communication, the third component of disciplined inquiry, entails written and oral conversation that goes beyond recitation. Students need to express their ideas through words, symbols, and products, with other students and with others more experienced in the field.

\subsubsection{Value beyond Instruction}

Engaging students in tasks that have value beyond the immediate activity is the third intellectual quality standard. "Authentic achievements have aesthetic, utilitarian, or personal value apart from documenting the competence of the learner” (Newmann \& Archbald, 1992, p. 74). Giving students the chance to work on realistic problems or communicate their understanding to an audience outside of school, adds value to the task that goes beyond learning content simply to advance in school.

The idea that learning involves a deepening process of participation in a community of practice has gained significant ground in recent years (Smith, 2003). Professional Learning Communities (DuFour, Eaker, \& DuFour, 2005) are examples of educational communities that share common cultural characteristics. "Reculturing" of schools is necessary to promote the type of reform advocated by the CCSS and that gets to the heart of education and schools - improved student achievement through authentic learning. The characteristics of communities of practice, professional learning communities, and the ILT model hold potential to help facilitate this necessary reculturing. 


\subsection{Professional Learning Communities}

One way to analyze Instructional Learning Teams is to situate them against the research on professional learning communities and the collaborative work of teams within these communities. Initially, ILTs build communities of practice (Wenger, 1998). This means each member is expected to fully participate via collaboration and reflection on shared goals. One way to do this is to structure the conversations around objective measures, such as the task, the instruction, and students' work. Teachers will share in the collaborative process of building the lessons and reflecting on the pedagogical process leading up to student performance (Fullan, 1993; Rogoff, Turkanis, \& Bartlett, 2001; Stewart \& Brendefur, 2005a).

Fullan (2001) stated that "most strategies for reform focus on structures, formal requirements, and event-based activities [that] do not struggle directly with existing cultures and which new values and practices may be required" (p. 34). Reculturing is necessary for change to occur and be sustained. It is how teachers come to question and change their beliefs and habits (Fullan, 2001). A fundamental way to reculture schools is transform them into professional learning communities (DuFour \& Eaker, 1998; DuFour et al., 2005; Hord, 1997), but to do so requires providing structures that support objective discourse focused on student learning and practice. The idea is to promote school improvement while also providing a process through which teachers focus on deep school-wide learning issues, collaborate with other professionals, and have time for sustained reflection about beliefs and practices.

Researchers have listed critical elements essential to creating professional learning communities: shared norms and values, a focus on student learning, reflective dialogue, deprivatization of practice, collaborative teams, action orientation and experimentation, continuous improvement, and a results orientation (DuFour \& Eaker, 1998; Louis, Kruse, \& Marks, 1996). After briefly describing the first four elements listed above, we use these elements as a lens to analyze the strength of the ILTs and our initial research questions. This integration provides a more robust and triangulated body of research to support the ILT process.

\subsubsection{Shared Norms and Values}

To bring teachers and administrators together for the purpose of participating in a professional learning community they must share a common vision of values central to teachers' work. Shared understanding of common values and a collective commitment to guiding principles are what separates a leaning community from traditional school faculty. These guiding principles include such things as teachers' beliefs about students' ability to learn, priorities in education, and the roles of parents, teachers and administrators. The following questions must be asked: What must all students know and be able to do? How do we facilitate and measure student learning? How will we respond when students do not learn? How will we respond when students do learn?” These questions must be asked and the answers clearly communicated with parents and students and reinforced by the actions and practices of teachers and the school or even school district as a whole. Mission, vision, and values are integrated into each element essential to learning communities.

\subsubsection{Focus on Student Learning}

By focusing on student learning, teachers begin to professionalize their discussions. Asking what is most important for students to learn and how we develop student understanding and application of curricular concepts becomes the driving force of change. Attention to student and faculty learning is the core of professional learning communities (Hord, 1997). Faculty discussions and actions centered on enhancing student learning through instruction are the basis for improving opportunities for learning. By collaborating and communicating with other teachers this focus on learning, a clear consistent message is developed and sent to students.

\subsubsection{Reflective Dialogue and Collective Inquiry}

Collaborative reflection on curriculum, instruction and student development can lead to a greater awareness of the practice of teaching and its effect on students. Continual questioning of the status quo, testing strategies, teaching methods, and educational practices is the catalyst for growth in a professional learning community. Collective inquiry can lead participants to recognize that the process of searching for answers is often more important than having an answer. However, collaborative teams need structures and tools to support this type of reflection and inquiry.

\subsubsection{Deprivatization of Practice}

Deprivatization of practice works together with reflective dialogue and collective inquiry. In order to remove isolation, teachers must engage in dialogue. They discuss gaps left by teaching materials and offer alternative ideas and supplemental materials. Teachers share and analyze student work samples and lesson plans, exposing their 
practice to others and opening the door to collaborative improvement. It is also helpful to have teachers discuss ideas with teachers a grade below and above through vertical collaboration (Jacobs, 2010). This allows teachers to better understand prior and future expectations.

These issues can be overwhelming for a teacher working alone. Peers can be a source of insight and feedback which helps improve instruction. By sharing uncertainties about teaching, teachers can learn to talk about what it is they do when they are teaching and create a supportive environment (Warren-Little, 1999). The idea of collaboration is simple - get teachers together to discuss learning and teaching. However, without clearly defined norms, protocols, and purpose, many collaborative teams flounder and fail to directly influence increased student engagement and achievement (Secada \& Adajian, 1997). The ILT process has potential to support this type of instructional improvement and teacher learning. In order to validate this conjecture, we studied teams as they engaged with the ILT process.

\subsection{Research Questions}

The research questions guiding this investigation are: 1) How does the ILT model influence teachers' instructional practices? 2) In what ways does instructional, learning, and achievement discourse change over the course of the study? Four elements of professional learning communities were used to frame the findings from qualitative research methodologies employed to begin answering these questions. Additionally, rubrics developed by Newmann, Secada, and Wehlage (1995) and modified by Stewart and Brendefur (2005a) were used to frame discussions and analyze instruction.

\section{Methods}

A middle school and elementary school were selected to be part of the study, which included a multi-disciplinary middle school team and two elementary teams. Each school was located in the Intermountain West and was comprised of teachers with no single subject area expertise.

\subsection{Participating Schools}

Emery (pseudonym) is a middle school in the Intermountain West attended by approximately $7006^{\text {th }}-8^{\text {th }}$ grade students. Forty teachers are employed on the instructional staff. While there is a building administrator to oversee daily operations, this district employs a chief educational officer or "CEO" and an instructional guide to direct instruction for this and two other schools. The ILT at this school was composed of a team leader and five teachers. Although they were in close physical proximity to one another, these teachers did not share similar grade levels or curricular subject areas. They taught a variety of subjects, including art, special education, language arts, world history, and Title One reading. The team decided upon developing teaching strategies for using writing in their classrooms as their focus, and met 12 times after school from January to May for approximately two to three hours per week.

Wells (pseudonym) is an elementary Title One school with approximately 500 students Kindergarten through sixth grade and located in an urban city in the West. Fifty-four percent of the students received free or reduced lunch. This instructional learning team met regularly once a week throughout a semester. The team consisted of a second, third, two fourth, and one fifth grade teacher. They focused on both language arts and mathematics lessons. A team leader guided and oversaw the meetings teams.

\subsection{Data Sources and Instruments}

The first task of the team was to familiarize themselves with components of the Japanese lesson study and principles of intellectual quality. Three rubrics from Stewart and Brendefur (Stewart \& Brendefur, 2005b) were used to score (1) the combined major tasks in the lesson plan, (2) classroom instruction, and (3) student work. All meetings and instructional sessions were videotaped. The video tape was used for both research purposes (described next) and for professional development purposes, which provided opportunity for critiquing, reflecting, modifying, and improving at all stages of the ILT cycle.

The goal for the ILTs was to create a lesson and move through the following process:

1) Lesson Plan Design: One teacher would take the lead and design and share a lesson plan. Each lesson plan had to include (a) goals and standards, (b) the key or major tasks to be presented to students, and (c) any follow up questions or formative assessments. 
2) Score Task(s): Through structured conversation, the ILT scored the lesson they had designed, using the Task rubric. (Note: Each team was part of a 15 hour professional development session facilitated before school started where they learned how to use the Intellectual Quality rubrics).

3) Modify Tasks: Based on the task scoring and team conversations, the lesson plan and tasks are modified.

4) Teach and Video: Team members observe one teacher teaching the modified lesson plan, while the facilitator videotapes the instruction. Each member observes one group or area of the room and takes notes on students' actions and responses to the task and questions posed by the teacher. Many times the lesson covered one to three approximately fifty minute lessons.

5) Score Instruction Rubric: At the next meeting, the team members watch the videos or excerpts from them and critique the instruction using the Instruction rubric.

6) Collect and Score Student Work: The team member teaching the lesson collects student work from the taught lesson(s). At the following ILT meeting, each team member sorts student work into low, medium and high level samples and evaluates the work using the Student Work rubric.

7) Modify Lesson: Based on their critique of student learning, the team members make additional modifications to the lesson. They revisit the lesson and honed instruction to the point which, ideally, they know what part of the instruction was responsible for advancing learning, and what part was not effective.

8) Repeat the cycle (steps 1-9) for new lessons.

Throughout this study, all lessons were videotaped as they were taught and the student work collected following the conclusion of the lesson(s). Using the rubrics as the evaluation framework, the teams met to critique the instruction and the student work. These discussions were audio-taped by project personnel. In addition, team documentation was collected, including team notes, agendas, rubrics, and video tapes.

\subsection{Data Analysis}

To analyze the data (videos of lesson plans and audio-tapes of the ILT sessions) we used a general inductive approach (Thomas, 2006) and qualitative techniques (Erickson, 1986; Schatzman \& Strauss, 1973; Wolcott, 1994). All video and audio data were transcribed. Then, our process included a first read of the data in which initial and general coding took place. To ensure reliability of the codes, two readers discussed their results until consensus was reached. Through this process, general themes were identified. These themes emerged from both the literature review and this initial reading and are described below.

The general themes were then utilized to frame a second and more intense reading of the data. During this reading, categories within each of the themes were identified. Two readers met, discussed and refined the coding until consensus was reached. At this point, general assertions, largely through induction, were made for each category. The data were read a third time to search for confirming and disconfirming evidence to justify the assertions. Classes of data were organized and relationships were drawn, where possible, between these classes. These relationships allowed further analysis.

Initially, the general themes were found based on the literature and the reading: construction of knowledge, depth of inquiry, and value beyond instruction. Through a second read of the data, categories within each theme were coded using elements of PLCs: shared norms and values, focus on student learning, reflective dialogue and collective inquiry, and deprivatization of practice.

\section{Results}

\subsection{Shared Norms and Values}

\subsubsection{Emery}

Louis, Kruse, \& Marks (1996) state that "shared values find expression in school practice” (p.181). Although Emery's Website states "Our mission is to challenge students to become confident, self-directed, lifelong learners who are responsible citizens within their communities," some members of this instructional learning team were initially concerned about shared norms and values because of their mixed subject areas and curricular differences. They questioned whether they would be able to come together to improve instruction and raise student achievement.

The supportive environment of the team, however, allowed these teachers to express their concerns over differing curricular areas and instructional techniques. "Because our team was made up of teachers from different disciplines 
and differing levels of experience,” one team member wrote, "we got varied perspectives.” And as Louis et al. (1996) describes, "when exchanges are most fruitful, colleagues air differences in a context of trust and respect for each other's professional skills and contributions to the school community" (p. 187), thereby increasing shared norms and values.

As the team from Emery progressed through the instructional learning team process, the use of the intellectual quality principles helped focus and strengthen the shared values and norms across disciplinary boundaries. The art teacher commented, "I had always limited my writing assignments to short journal responses to art images. Yet through the use of the planning guides and other helpful materials, as well as strategies seen at work in other classrooms, such as peer review and the effective use of rubrics, I developed a longer term writing unit." Another teacher wrote, "our experience attests to the fact that teachers, working together for a common goal, create a synergy that yields results often surpassing an individual's results."

\subsubsection{Wells}

Visual evidence of shared norms and values was evident in Wells. Each hallway was carefully decorated with posters showing different values such as "Trust" and "Honesty." Teachers purposefully modeled and reinforced these values and expected both students and other adults to do the same. All teachers in Wells also participated in a district-wide continuous school improvement model and accompanying guidebooks were usually open and in use on teachers' desks. Although these instructional learning teams began with a more common curriculum and grade level than that of Emery, they also grew closer in shared values and norms as they made use of authentic pedagogy. A fifth-grade teacher wrote, "By the time we put our lessons together, we were beginning to think with the rubrics in mind," demonstrating a new norm emerging.

\subsection{Collective Focus on Student Learning}

\subsubsection{Emery}

As they progressed through the instructional learning team process and became familiar with authentic pedagogy, the focus on student learning increased and became more collective in Emery. While they first concentrated on the instruction rubrics, they soon saw the value of scoring student work and aligning it with instructional change. A language arts teacher wrote, "I marvel at the growth of student performance throughout the revision process as evidenced by our ILT outcomes.” The team leader added, "Although we taught different subjects, the ultimate goal was the same, we wanted to help our students become better writers. Examination of the student work samples of three of our members offer us hope that by May, student writing improved. In each of their classes we found evidence of student growth in voice, elaboration, organization and conventions. We can link their improvements to student tasks that showed high levels of value beyond school, construction of knowledge, and higher order thinking skills." The school CEO commented, "my involvement in the ILT program has allowed me to gain knowledge of leadership strategies that support a school culture of high expectations, continuous improvement, and learning communities that advance student achievement.”

\subsubsection{Wells}

Although the instructional learning team meetings contained reflective dialogue at Wells, the short and hurried before-school times of the meetings limited the deepness of discussion and reflection. The team only watched portions of the videotaped lesson. And, they scored the instruction, tasks, and student work in the same session. Even with a lack of truly deep reflection, however, team members still felt the results of reflective dialogue. A fifth-grade teacher commented, "There is more focus on our desired result." A third grade teacher stated, "By looking at the scores of student work, we see what expectations we have for kids. At first we were shocked by how low the scores were, but over time we started to change the tasks we gave students and asked them deeper questions."

\subsection{Reflective Dialogue}

\subsubsection{Emery}

Each meeting of the instructional learning team at Emery contained significant amounts of reflective dialogue. Predictably, even more useful and focused reflection occurred as team members became more comfortable with each other, with authentic pedagogy, and with the use of the rubrics. The meetings had no time limit and took place after school, yet, one teacher commented "Our afternoon meetings might appear to be a sacrifice; however, I found them energizing and stimulating. After each session, I left with a renewed vigor to apply new insights in my classes."

The reading teacher wrote, "We bring lessons to be scrutinized by our colleagues without the fear of being ridiculed. I felt I was being mentored in the truest sense of the word. As we spent time together, we learned to value each 
other's opinions." The history teacher added, "We learned to stick to the language of the rubric and offer ways to increase the quality of each person's instruction. We had a powerful, thoughtful, and helpful team. This personal interaction has been priceless to me.” Even more powerful were comments from the team leader, who wrote "These...individuals took the groups' reflections, critique, and comments to the heart of their instructional practice, made deep revisions in their work, and saw growth in student skill as a result."

\subsubsection{Wells}

Critiquing lessons, applying rubrics, and viewing videotaped lessons created a venue for reflective dialogue. Rich discussion led to a deeper understanding of authentic pedagogy and student learning. By revisiting the lesson and discussing it, the teacher's honed the instruction until they knew what part of the instruction was responsible for advancing learning, and what part was not effective. The ILT teachers discussed changes they would make next time and then modified the lesson.

As a result of this reflective dialogue regarding collecting and scoring student work teachers became aware that students had trouble communicating mathematics. This led to an interesting discussion of the gaps in mathematics education. Explaining the process of solving problems, their application to real life and connections to previous concepts is not traditionally expected of students. Ideas to resolve these issues and interventions to help remove these gaps were discussed.

Teachers on the team were able to witness the scaffolding effect of a fraction lesson and discuss the various levels of students' development. The third grade teacher understood what the second grade teacher taught and what she should pass on as a knowledge base to fourth grade and so on. Due to the collaborative effort and communication among these teachers their expectations were made known and adjustments in taught lessons occurred.

Discussions were considered the most powerful part of the ILT process. As a group, discussing the lessons each created is where the team experienced the idea of reflective dialogue and vertical teaming in action. Because grades 2 , 3, 4 and 5 were represented each member contributed expertise from their grade level. The scaffolding effect was prominent. Each contributed questioning strategies, resources (books, videos, and manipulatives) and assessment methods that worked for them at their grade level. The task rubric guided them. The scoring scale of this rubric was one through four. They would discuss the requirement of each level and make suggestions such that they could raise the level. It was noted that some tasks were designed to be at the one level and that was okay; not all tasks were meant to be scored at the high end of rubric. For example the second grade teacher asked students to write a fraction on their white boards and flash it to the class. This is a basic task and scored a one on the rubric. This task served its main purpose to determine whether students could demonstrate an ability to write a fraction.

\subsection{Deprivatization of Practice}

\subsubsection{Emery}

As stated previously, "by sharing uncertainties about practice, teachers learn new ways to talk about what they do...the typical norm of individual autonomy is diminished, and teachers become committed to practicing their craft in public ways” (Louis, Kruse, \& Marks, 1996, p.183). The team members from Emery were initially nervous at the thought of being videotaped and critiqued by other team members. As team members became more comfortable with this process and the use of rubrics to comment upon and change instruction, they indeed began to practice their craft in a more public way. The compelling element of the group, the team leader wrote, "is the manner in which they came together to critique and support each other to improve their classroom practice."

\subsubsection{Wells}

Team members at Wells were reluctant to videotape themselves during classroom instruction. A few teachers finally consented and when they began discussions, their attitudes changed. Lively conversation began within the ILT meetings and all the teachers said they left excited and motivated to continue this process. The more they worked together the more comfortable they became with their contributions to the group. They established a level of trust. This will be beneficial if the program expands. One teacher suggested that perhaps the level of trust was high because they did not teach the same grade. There was not the feeling of competition. Collaboration exposed them to where they were at that time, what they wanted to pass on to the next grade and what they expected from the grades below them. A fifth grade teacher stated, “While the lesson is planned jointly, it hasn't become prescriptive. Before, I might try a lesson one way, and if it didn't work, it might be a difficult to find another effective way to teach the same concept. Now, I have a new mindset that tells me, if I don't know how else to teach this, or if a few students are still having difficulty, it’s good to know I have other teachers to collaborate with.” 
The ILT teachers expressed a major benefit of this process was the vertical teaming and communication among teachers at different grade levels: the process of deprivatization. Teachers discussed the various skills they wanted in a class when the class was passed on to the next grade. Each teacher discussed expectations of the students at each grade level.

\section{Discussion}

It was found that the manner in which teachers engaged in conversation about instruction, learning, and achievement were qualitatively different. Teachers began to refer to their observations in terms closely aligned with those of authentic pedagogy. In addition, teachers were acculturated into a collaborative environment designed to foster reflection and systematic investigation.

Individually, teachers created a lesson and came together to score it using the task rubric as a guide. Using the rubric, teachers collaborated and modified their lessons. Then teachers' video-taped instruction and gathered student work. At subsequent meetings they used rubrics to rank their instruction and student work. This process led to deeper discussion of how to modify the current and future lessons. Teachers expressed a major benefit in this process. By using the process of the Japanese Lesson Study with the focus of the Intellectual Quality rubrics, the team's ability to discuss, interpret and change their practices was heightened.

All ILT teachers stated the structure of the lesson plan cycle, the process of scoring rubrics, and the collaboration among peers changed the way they wrote, taught and evaluated lessons. Teachers identified the following factors as contributing to their success: starting small, establishing a level of trust among team members, setting aside time to collaborate, learning about the ILT model, planning for the logistics of videotaping instruction, keeping track of the data, and supportive administrators.

Analysis of these two schools and the interaction of their instructional learning team process, use of intellectual quality, and the elements common to professional learning communities yields mixed results. While both teams had some elements of professional learning communities at their inception, they actually acquired more of these elements as they progressed through the instructional learning team process and used the standards of intellectual quality to change instructional practices. Although further study is necessary, these teams may not have acquired these elements had they not used the intellectual quality rubrics.

Because of the length of their meetings and the ability to have deep and focused reflective dialogue, it also appeared that the instructional learning team from Emery more deeply internalized the elements of a professional learning community and the elements of authentic pedagogy. This internalization and resulting change of instructional practice impacted the types of student work they sought for and based on testimony from the teams began to improve student achievement and understanding. They also deprivatized their practice to a greater extent, consistently focused on student learning, and more effectively collaborated as a team. In fact, the team at Emery was so successful; the entire school began participation in this process.

While there were a few highly influential variables missing, such as active participation by administrators, all team members from both schools believed that their teams were successful and, although to varying extents, felt their practices and beliefs were changed. DuFour \& Eaker (1998) state, "becoming a learning community is less like getting in shape than staying in shape-it is not a fad diet, but never-ending commitment to an essential, vital way of life" (p.28). A teacher from Emery echoed this very statement, commenting, "The instructional team philosophy is not just another fad or strategy to tryout in the classroom; rather, it has the potential to bring about a virtual revolution in teacher practices that can in turn have a powerful impact on student learning!"

According to Desimone (2009), in order to connect improved student outcomes to professional development, clear links must be established between the professional development experiences and, then, changes in teachers' knowledge, beliefs and attitudes, their instructional practices, and students' improved achievement. This study is not claiming improved instruction, but is clearly providing evidence of professional development experiences that may help teachers navigate which practices are effective and to what degree. This is an invaluable tool as we move toward implementing the practice and content standards in the Common Core State Standards (NGA, 2010) and sustaining the continuous improvement efforts of learning communities. 


\section{References}

Bellanca, J., \& Brandt, R. (Eds.). (2010). 21st century skills: Rethinking how students learn. Bloomington, IN: Solution Tree.

Borko, H., Jacobs, J., Eiteljorg, E., \& Pittman, M. E. (2008). Videos as a tool for fostering productive discussions in mathematics professional development. Teaching and Teacher Education, 24(2), 417-436. http://dx.doi.org/10.1016/j.tate.2006.11.012

Cochran-Smith, M., \& Lytle, S. L. (1993). Inside/Outside: Teacher research and knowledge. New York: Teachers College Press.

Darling-Hammond, L., Wei, R. C., Andree, A., Richardson, N., \& Orphanos, S. (2009). Professional learning in the learning profession: A status report on teacher development in the United States and abroad: National Staff Development Council.

Desimone, L. M. (2009). Improving impact studies of teachers' professional development: Toward better conceptualizations and measures. Educational Researcher, 38(3), 181-199. http://dx.doi.org/10.3102/0013189X08331140

DuFour, R., \& Eaker, R. (1998). Professional learning communities at work: Best practices for enhancing student achievement. Alexandria, VA: Association for Supervision and Curriculum Development.

DuFour, R., Eaker, R., \& DuFour, R. B. (2005). On common ground: The power of professional learning communities. Bloomington, IN: Solution Tree.

Erickson, F. (1986). Qualitative methods in research on teaching. In M. C. Wittrock (Ed.), Handbook of Research on Teaching (3rd ed., pp. 119-161). New York: Macmillan.

Frykholm, J. A. (2004). Teachers' tolerance for discomfort: Implications for curricular reform in mathematics. Journal of Curriculum and Supervision, 19(2), 125-149.

Fullan, M. (1993). The professional teacher: Why teachers must become change agents. Educational Leadership, 50(6), 12-17.

Fullan, M. (2001). The new meaning of educational change. New York: College Press, Columbia University.

Haycock, K. (2001). Closing the achievement gap. Educational Leadership, 58(6), 6-11.

Heck, D. J., Banilower, E. R., Weiss, I. R., \& Rosenberg, S. L. (2008). Studying the effects of professional development: The case of the NSF's local systemic change through teacher enhancement initiative. Journal for Research in Mathematics Education, 39(2), 113-152.

Henson, K. T. (1996). Teachers as researchers. In J. Sikula (Ed.), Handbook of research on teacher education (pp. 53 - 64). New York, NY: Macmillan.

Hiebert, J., \& Stigler, J. W. (2000). A proposal for improving classroom teaching: Lessons from the TIMSS video study. Elementary School Journal, 101(1), 3-20. http://dx.doi.org/10.1086/499656

Hord, S. M. (1997). Professional learning communities: Communities of continuous inquiry and improvement. Austin, TX: Southwest Educational Development Laboratory.

Jacobs, H. H. (2010). Instructional cartogrophy: How curriculum mapping has changed the role and perspective of the teacher. In R. Marzano (Ed.), On excellence in teaching (pp. 195-211). Bloomington, IN: Solution Tree Press.

Lampert, M., \& Ball, D. L. (1999). Aligning teacher education with contemporary K-12 reform visions. In L. Darling Hammond \& G. Sykes (Eds.), Teaching as the learning profession: Handbook of policy and practice. San Francisco: Jossey-Bass.

Lewis, C. (2002). Does lesson study have a future in the United States? Nagoya Journal of Education and Human Development, 1, 1-23.

Louis, K. S., Kruse, S. D., \& Marks, H. M. (1996). School wide professional community. In F. M. N. Associates (Ed.), Authentic achievement: Restructuring schools for intellectual quality (pp. 179-203). San Francisco: Jossey-Bass.

MSEB. (1990). Reshaping school mathematics: A philosophy and framework for curriculum. Washington, DC: Mathematical Sciences Education Board: National Academy Press. 
NCTM. (2000). Principles and standards for school mathematics. Reston, VA: National Council of Teachers of Mathematics.

Newmann, F. M., \& Archbald, D. A. (1992). The nature of authentic academic achievement. In H. Berlak, F. M. Newmann, E. Adams, D. A. Archbald, T. Burgess, J. Raven \& T. A. Romberg (Eds.), Toward a new science of educational testing and assessment (pp. 71-83). Albany, NY: State University of New York Press.

Newmann, F. M., \& Associates. (1996). Authentic achievement: Restructuring schools for intellectual quality. San Francisco, CA: Jossey Bass.

Newmann, F. M., Secada, W. G., \& Wehlage, G. G. (1995). A guide to authentic instruction and assessment: Vision, standards and scoring. Madison, WI: Wisconsin Center for Education Research, University of Wisconsin-Madison.

NGA. (2010). Common core state standards for mathematics. Washington DC: National Governors Association and the Council of Chief State School Officers.

Nye, B., Kostantopoulos, S., \& Hedges, L. V. (2004). How large are teacher effects? Educational Evaluation and Policy Analysis, 26(3), 237-257. http://dx.doi.org/10.3102/01623737026003237

PARCC. (2013). Partnership for Assessment of Readiness for College and Careers. Retrieved from http://parcconline.org/

Rogoff, B., Turkanis, C. G., \& Bartlett, L. (2001). Learning together: Children and adults in a school community. New York: Oxford University Press.

SBAC. (2013). Smarter Balanced Assessment Consortium. Retrieved from http://www.smarterbalanced.org/

Schatzman, L., \& Strauss, A. (1973). Field research: Strategies for a natural sociology. Englewood Cliffs, NJ: Prentice Hall.

Secada, W. G., \& Adajian, L. B. (1997). Mathematics teachers' change in the context of their professional communities. In E. Fennema \& B. S. Nelson (Eds.), Mathematics teachers in transition. Mahwah, NJ: Lawrence Erlbaum Associates.

Smith, M. K. (2003). Communities of practice. The encyclopedia of informal education, Retrived from www.infed.org.biblio/communities_of_practice.htm

Stewart, R. A., \& Brendefur, J. L. (2005a). Fusing lesson study and authentic achievement: A model for teacher collaboration. Phi Delta Kappan, 86(9), 681-687.

Stewart, R. A., \& Brendefur, J. L. (2005b). Fusing lesson study and authentic achievement: A model for teacher collaboration. Edge, 1(1), 1-20.

Stigler, J., \& Hiebert, J. (1999). The teaching gap: Best ideas from the world's teachers for improving education in the classroom: Freedom Press.

Thomas, D. R. (2006). A general inductive approach for analyzing qualitative evaluation data. American Journal of Evaluation 27(2), 237-246. http://dx.doi.org/10.1177/1098214005283748

Warren-Little, J. W. (1999). Organizing schools for teacher learning Teaching as the learning profession: Handbook of policy and practice (pp. 233-262).

Wenger, E. (1998). Communities of practice: Learning, meaning, and identity. New York: Cambridge University Press. http://dx.doi.org/10.1017/CBO9780511803932

Wolcott, H. F. (1994). Transforming qualitative data: Description, analysis, and interpretation. Thousand Oaks, CA: Sage.

Zeichner, K., \& Gore, J. (1990). Teacher socialization. In W. R. Houston (Ed.), Handbook of Research on Teacher Education (pp. 329-348). New York, NY: MacMillan. 